\title{
Attitudinal Impact of Institutional Mechanisms of Public Accountability and Performance among Local Government Workers in Nigeria: A Study of Enugu State Local Governments
}

\author{
Agu Sylvia Uche (Ph.D) \\ Department of Public Administration and Local Government, University of Nigeria, Nsukka \\ Email:uchesagu@yahoo.com \\ Okeke Remi Chukwudi \\ Department of Public Administration and Local Government, University of Nigeria, Nsukka \\ Email:remiokeke@gmail.com \\ Idike Adeline Nnenna \\ Department of Public Administration and Local Government, University of Nigeria, Nsukka
}

Doi:10.5901/mjss.2015.v6n5p403

\begin{abstract}
Our conviction that there is need for improved services in the local government system provided an impetus for assessing the attitude of local government workers towards the application of institutional mechanisms of public accountability and the effect on performance. 205 local government functionaries completed a questionnaire. The mean age, qualification and length of service of the respondent were 2.5, 2.60 and 2.58 respectively. The hypothesis was tested at 0.5 significant levels using contingency coefficient. The study established that attitude of local government functionaries towards the application of these mechanisms significantly correlate with performance. Implications of these findings are discussed.
\end{abstract}

Keywords: Attitude, institutional, mechanisms, local, government accountability

\section{Introduction}

Governments all over the world are reforming and strengthening their systems of local governments and decentralizing responsibilities to sub national levels. This process is driven by different factors in every country political, economic, and social as well as external influences. The common underlying belief is that shifting responsibilities for service delivery to the local levels should help in ensuring that decisions and resources reflect the needs and priorities of the citizens. This belief however, is dependent on the quality of decisions made by local governments concerning the delivery of services and the use of resources locally, (Raffia; 2005). Yet, it is well known that representative democracy per se is not necessarily the best way of establishing local needs and preferences. It needs to be accompanied by more sensitive and effective mechanism for ensuring that public officers are accountable and transparent in using public funds at the local levels. Such mechanisms are often resisted by those who are controlling the institutions of local governments. Local governments were established with the specific functions to assist the two higher tiers of government viz. state and federal to bring effective rural development and good governance to the grassroots level (Nwankwo; 2004). According to Nwankwo, one of the strategies adopted by local governments to bring about effective rural development and good governance to the grassroots level in Nigeria is the provision of social services to ensure sustainable development in the local governments. Between June 1999 and June 2003, the Etsu Nuper Ciroma (technical committee on review of local government in Nigeria carried out a research on the fiscal and physical evaluation of the performances of the third tier level of government.

This study revealed that this level of government has performed below standard especially in physical development and provision of social welfare services required to enhance the quality of life. In-addition, in a study carried out by AFROBAROMETER, in 2008 on the performance of Local Governments. The public clearly consider that the local governments have failed in the performance of their primary duties, namely service delivery and resource mobilization. This poor record development of local governments was linked to poor fund management. In-addition, many studies have 
linked the poor development record of local governments to inadequate funding and financial autonomy. Elekwa (1996) notes that local governments do not have substantial degree of autonomy to engage in any meaningful development and this constitute a great problem to funding and performance. However, though important the quantum of funding is perhaps not as crucial an issue in the performance of local governments as the efficacious operation of the various institutional mechanisms installed in the local government system to ensure public accountability. Are these mechanisms in operation? How effective are they? Usually those elected as local government chairmen are not career officials and may not be keen at adhering to and sustaining the operations of these mechanisms. However, positive attitude towards the application of these mechanisms will, to a great extent influence public accountability and performance. Attitudes are the feelings and beliefs that largely determine how employees will perceive their environment, commit themselves to intended actions and ultimately behave. A good attitude, on the other hand, opens doors of opportunity for you, and, if you're a manager, helps boost your employees' productivity (Melisa,2010). Velnampy(2006 ) strongly believes that attitudes form a mental set that affects how we view something else and has an impact on how we view and judge our surroundings at work. Attitude of the employees towards application of the organizational mechanisms are important to achieve the individual and organizational objectives. Attitude towards institutional mechanisms are the feelings that workers have towards application of the mechanism for effective performance. Carpeter et al enumerated some elements which influences the attitude towards works -personality, person-environment fit, job characteristics, psychological contract, organizational justice, work relationship and stress. Staw et al in Susanty (2013) refers to the functions of attitudes as the emerging and facilitative effects of positive affect. Riketa (2009);in conjunction with staw et al, Robinson(2001) and some researchers indicate that job satisfaction is concerned with several attitudes including attitudes about the job characteristics, compensation and benefits, status, sok2cial security, advancement, opportunities, technological challenges and respect. There has been a serious debate from the field of the behavioral sciences on the attitude performance problem. Scholars like Luu (2011); Eagly and Chaiken (1998);Mathieu and Zajac (1990); Meyer et al(2004); and Wei and Chu(2008) strongly argue that attitude functions as guidelines and facilitators behavior. In a study carried out by Wei and Chu (2008), they discovered that work attitude has a positive effect on job performance. Better job attitude leads to better job performance. In the same, vein we infer that attitude of employees towards the application of the mechanisms for public accountability significantly correlate with performance of the organization. These mechanisms include auditing framework, budgetary process, parliamentary oversight functions of local governments and state legislature assemblies, public procurement bill, bank reconciliation statement etc. All these mechanisms are installed in the three tiers of governments to ensure public accountability and performance. Based on the above, this study predicts that attitudes of local government functionaries towards the operations of institutional mechanisms of public accountability impact positively/negatively on the performance of the organization.

\section{Significance of the Study}

Nigerian governments, in their various epochs have evolved several reforms to make and integrate local governments into the main stream of the nation's administration and financial system. Most of these reforms have not really solved the problems of local governments. A lot of problems have been encountered which have threatened the existence of local governments. For example, non-adherence to the processes and requirements to the various institutional mechanisms constitute one of the crucial problems confronting local governments' administration in Nigeria. The study is thereof, theoretically and empirically significant. Theoretically, it will add to literature or rather serve as a source document for further research in this area. In addition, the outcome of the research will provide an alternative interpretation between the functioning of these institutional mechanisms in terms of output and performance. Furthermore, it will bring to light in a coordinated and systematic form, the problems and prospects of non-implementation of these mechanisms. Empirically, local governments functionaries will benefit from the study, as it will enable them get acquainted with the main, institutional mechanisms of public accountability, which have been hitherto neglected. The research will be of immense value to the communities since the knowledge; attitude, and mere implementation of these mechanisms will ultimately stimulate increased development and strengthen the bond between the people and their leaders at the local levels.

\section{Theoretical Framework}

The institutional theory has become a prominent lens through which organizational processes of continuity and change are interpreted and understood. It is concerned with the development of open systems of organization (Silverman; 1970: Preffer and Delbridge; 2005). Such system emphasizes the significance of social and cultural aspects of organizational environments rather than the task and technical elements given prominence under contingency theory and resource 
dependency theory (see Donaldson, 1995; Oliver 1991). However, much of the early theorizing from an institutional perspective was concerned with an alternative to functional and rational explanation of organizational forms (Meyer and Rowan 1977: Rachel et al. 2005) and sought to understand similarity and stability within organizational field (Dimaggio and Powell, 1983). Organizational environment can be characterized by the sources of norms, and values which permeate organizations and influence action in particular by informing the "taken for granted" assumptions regarding behaviors, organizational forms and processes that are seen as legitimate. Dimaggio and Powell (1983) identified ways that an organization within a field fence pressure to conform, to forms and processes deemed legitimate. These pressures as identified by them are; mimetic, coercive and normative. For the purpose of our theoretical framework, the normative and coercive factors are the most crucial. These normative and coercive factors are product of societal norms and constitutional legal framework predominant over a period of time. The normative factor constitutes the standards to adopt to achieve performance while on the other hand, the role played by coercive forces highlights political impact. Dimaggio and Powell identified roles played by the federal government to ensure compliance of the several mechanisms installed in the three tiers of governments to ensure accountability and improved performance. The term compliance, suggests that over time organizations are moving in the direction of movement that is required by prevailing institutional norms and the target organizational characteristics that are expected to change. The expectation of the institutional theory is that there should be institutional logics/mechanisms that underpin the organizing principle of the field. In Nigeria local government systems, we have the institutional mechanisms for public accountability. If local government functionaries display positive attitude towards the application of these mechanisms, it would, to a great extent, enhance performance.

\subsection{Sample}

The sample in the present study consisted of 205 local government functionaries. The focus of the study was Enugu state. Enugu state is situated in the southern part of the country and is made up of 17 constitutional local governments and 56 development centers. The local governments are Aninri, Awgu, Enugu east, Enugu North, Enugu South, Ezeagu, Igbo-Etiti, Igbo-Eze North, Igbo-Eze South, Isi-Uzo, Nkanu East, Nkanu West, Nsukka, Orji River, Udenu, Udi and UzoUwani,. To facilitate data collection, the study was focused on 3 urban and 3 rural local governments. The local governments were Nsukka, Udi, Enugu-North, Igbo-Eze North, Nkanu and Ezeagu. The population is made up of 100 female and 140 male, 240 questionnaires were mailed to 6 local governments in Enugu state. (40 in each local governments) About 31-36 people filled the questionnaires. However, those in finance were more than half the number. There were no differences between the number that filled the questionnaires in the urban and rural local governments. The mean of the qualification and length of service are 2.60 and 2.58 respectively.

\subsection{Instrument}

A structured questionnaire on workers attitude towards the application of these mechanisms and also the effect on performance were used for the collection of data. We also interviewed workers to validate our data. The purpose of the quiz is to assess attitude of the respondents about institutional mechanisms of public accountability and its effect on performance in Nigeria local governments. The first part of the questionnaire solicited personal descriptive information from the respondents.

\subsection{Procedure}

Local government functionaries were chosen from three urban and three rural local governments in Enugu state. The stratified random sampling technique was used to select the six local governments from the three senatorial districts, and then a purposive random sampling technique was used to select respondents to be included in the study. The use of purposive random sampling technique enables the researcher to pick those that best met the purpose of the research. This however nullifies the use of any simple percentage to get the number of people to respond to the questionnaires. However, the questionnaires were purposively administered to mainly finance officers in the local governments and then some other category of staff that answered the questionnaires perfectly well. This is because; the study is on attitude of workers to institutional mechanisms of public accountability and performance in Nigeria local governments. Therefore, mainly finance officers and some key officers will understand the content of the questionnaires better. Local government functionaries were informed that the research was purely for academic purpose and that all participants would remain anonymous. 


\subsection{Independent Measure}

Attitude of workers towards the application of institutional mechanisms of public accountability was analyzed using attitude and strict application of the various institutional mechanisms put in place. The assumption here is that if local government functionaries display positive attitude towards the application of these mechanisms, it would significantly correlate with performance of the organization. The variables that make up positive attitude are stated herein.

\section{Results and Findings}

The research sought to provide answers to the following:

Attitude of local government functionaries towards the application of the "Institutional Mechanisms" of public accountability impact positively/negatively on performance.

Table 1: Descriptive data on workers view on attitude and application of Institutional mechanisms of public accountability and performance

\begin{tabular}{|c|c|c|c|c|c|c|c|}
\hline Item & Frequency & $\%$ & No & $\%$ & - & $\%$ & Mean \\
\hline 1 & 136 & 66.3 & 68 & 31.7 & 4 & 2.0 & 2.01 \\
\hline & Very good & & Good & & Better & & \\
\hline 2. & Frequency & & & & & & \\
\hline & 65 & 31.7 & 100 & 48.8 & 40 & 19.5 & 2.07 \\
\hline 3 & Very pleased & & Pleased & & Not pleased & & \\
\hline & 73 & 35.6 & 92 & 44.9 & 40 & 19.5 & 2.03 \\
\hline & VHPE & & HPE & & PE & $\%$ & \\
\hline & 104 & 51.39 & 42 & 20.5 & 59 & 28.8 & 2.55 \\
\hline
\end{tabular}

VHPE-Very high positive effect

HPE High positive effect

PE Positive effect

Table 1 presents percentage data regarding workers view on attitude of workers towards institutional mechanisms of public accountability. According to these data, workers respond favorably well to the questions. Item I shows the percentage of those in the local government system who accept and believe in these mechanisms of public accountability. Acceptance in the sense that they: displays good mood when working; always try to resolve the problem related to the application of the work; feels good about the mechanisms; and strongly believe that the application of these mechanisms would impact positively on the local governments. However, given that acceptance is not practice but we intend to know the general opinion of workers on the mechanisms. An overt majority (66.3\%) accepted and believed in these mechanisms of public accountability while $31.7 \%$ do not. An insignificant percentage $2.0 \%$ claimed not to know. We did not find this surprising given that acceptance and believe do not necessary mean application and also considering the answers to the questions during the interview session. Item 2 "feeling of respondents about the application of these mechanisms". Respondents feelings- the presence of justice related to the treatment of employees, always create a good relationship with his colleagues, never engaged in conflict when trying to apply the laws, always feel very safe in applying the mechanisms of public accountability, thinks very good of the organization and always willing to confront those who display lukewarm attitude towards the application of these mechk2anisms. Less than half the number felt very good (31:7\%) $48.8 \%$ felt good while $19.5 \%$ are not pleased with the mechanisms. item 3 on the other hand shows that almost all the workers in the local governments interviewed believed that these mechanisms will have positive effect on performance if implemented. It is believed that respondents really care about the fate of the organization, very easy to agree with the company's policies, and strong believe to maintain membership in the organization. Conclusively, we can deduce that local government functionaries display positive attitude towards the application of these mechanisms. The answers revealed that they felt good about these mechanism and also felt that the application of these mechanisms would have very high positive impact on performance. The mean of 2.55 reveals this important feeling of local government functionaries. They know the importance of these mechanisms in relation to the increased development of local governments.

During the interview session, local government staff interviewed expressed disappointment about non-application of these mechanisms of public accountability. They lament on the system of politicking in the local government systems. Some of them interviewed claimed that political office holders constitute the major clog on the progress of local 
governments. Some stated these as what is obtainable in the system- political office holders who pilot the affairs and are the engine room of Nigerian local governments do not really care about the fate of the organization; non-acceptance of the organizations' goals and values as the aim is to enrich their purse; unwillingness to exert effort on behalf of the organization; and lack of strong desire to maintain membership in the organization. Elected officials display negative attitudes towards achieving the aims for the creation of local governments rarely follow instructions which may be beneficial to the organization; and not careful in doing the job to achieve performance. In most cases the career officials connive with them to ensure indirect retrogression. Some of the officials interviewed, said that for local governments to apply these mechanisms religiously, that the political office holders must relinquish their duties and the vacuum filled with career officials who would be routinely checked or alternatively, sanctions already existing on the Revised Financial Memoranda 2001 be implemented on any offending officer irrespective of his/her position. They were optimistic that if these mechanisms of public accountability instituted in the system were strictly adhered to, they would ultimately lead to increased performance. The impact of this third tier government would be felt. Some of the principal officers narrated the procedure appointed by law for budgeting but confessed that this procedure is not applicable. They said that committee members that constitute the estimate committee and collect pieces of information or input are not constituted again. The practice, currently, is for the treasurer and his planning officer in most cases to formulate programs and projects. The consent of the chairman with regards to these programs and projects would be obtained. These programs and projects are then consolidated into a draft estimate and the treasurer goes to government house to defend the estimate. Consequently, government ratifies the estimate and after this stage, the estimate would be produced and presented to council members.

They further stated that the principal reason for non-compliance with the estimate preparation lies in the fact that the prepared estimate in most cases does not favor the chairmen. Once the estimate is prepared, it becomes a mere paper work not a working document because the chairman may intervene by presenting his personal needs that are not in the budget. Again, the estimate is seen as a copyright as a result of the approach used in budgeting in Nigeria that is the incremental approach to budgeting. Incremental approach is a method of budgeting. In this method, budgeting is prepared in view of the existing budget. Improvement only is made on the existing budget hence it is not innovative and does not allow for inclusion of new projects. In view of the results obtained from the answers to the question on attitude, we conducted a contingency coefficient to know the degree of association between attitude of local government functionaries to these mechanisms of public accountability and performance. We use the contingency coefficient because our data is a nominal data. (For nominal data no intrinsic order such as catholic, protestant and Jewish). You can select Phi-coefficient and cramer's v contingency coefficient, lambda (symmetric and asymmetric, lambdas and Goodman and Kruskal's tau) and uncertainty coefficient. Contingency coefficient is a measure of association based on chi-square. The value ranges between 0 and 1, indicating no association between the row and column variables and value close to 1 indicating a very high degree of association between the variables. The maximum value possible depends on the no of rows and columns in the table.

Table 2: Attitude and performance on health department

\begin{tabular}{|c|c|c|c|c|}
\hline Attid 1 & 14 & 26 & 15 & 45 \\
\hline 2 & 40 & 69 & 115 & 120 \\
\hline 3 & 21 & 14 & 3 & 38 \\
\hline 4 & 2 & 0 & 0 & 2 \\
\hline Total & 77 & 109 & 19 & 205 \\
\hline
\end{tabular}

Symmetric measure

\begin{tabular}{|l|c|c|}
\hline & Value & Approx sig. \\
\hline Nominal by nominal contingency coefficient & .219 & .112 \\
\hline N of valid cases & 205 & \\
\hline
\end{tabular}

a. No assuming the null hypotheses

b. Using and asymptotic standard error assuming null hypotheses

Attid * works perf.

Count cross tab 
Table 3

\begin{tabular}{|c|c|c|c|c|}
\hline & 1 & 2 & 2 & Total \\
\hline Attid 1 & 1 & 24 & 20 & 45 \\
\hline 2 & 10 & 69 & 41 & 120 \\
\hline 3 & 1 & 28 & 9 & 38 \\
\hline 4 & 0 & 2 & 0 & 2 \\
\hline Total & 12 & 123 & 70 & 205 \\
\hline
\end{tabular}

Symmetric measure

\begin{tabular}{|l|c|c|}
\hline & Value & Approx sig. \\
\hline Nominal by nominal contingency coefficient & .200 & .201 \\
\hline N of valid cases & 205 & \\
\hline
\end{tabular}

Attid * Health Performance.

Count cross tab

\section{Table 4}

\begin{tabular}{|c|c|c|c|c|}
\hline & 1 & 2 & 3 & Total \\
\hline Attid 1 & 8 & 32 & 5 & 45 \\
\hline 2 & 41 & 71 & 8 & 120 \\
\hline 3 & 16 & 20 & 2 & 38 \\
\hline 4 & 2 & 0 & 0 & 2 \\
\hline Total & 67 & 123 & 15 & 205 \\
\hline
\end{tabular}

Symmetric measure

\begin{tabular}{|l|c|c|}
\hline & Value & Approx sig. \\
\hline Nominal by nominal contingency coefficient & .223 & .096 \\
\hline N of valid cases & 205 & \\
\hline
\end{tabular}

The result of testing the association are presented in the above tables. An attitude towards institutional mechanisms of public accountability had a positive effect on performance but not quite significant on health's performance $\beta=.219, P<1$, so the association is very low. Positively associated but very low indicating a very low degree of performance in the health department of the local government systems. The result on works department is $\beta=.200, P<1$ indicating a very low association though positive. The result on education department is $\beta=.223, P<1$. They are all positively associated but relatively very low association. The employers and the appointed politicians had little interest in their work and failed to display positive attitude towards the application of the mechanisms. Consequently organizational commitment was lacking which is the most influential factor or a significant predator of job performance. However, the outcome of the research could be linked to the result of some scholars on relationship between commitment and organizational performance. See Bashaw and Grant (1994);Kallerberg and Marden(1995);Suliman and Lies(2000)Meyer et al (1984); Khanet al (2010) and Susanty and Miradipta (2013). These scholars discovered in their studies that there is a positive relationship between organizational commitment and performance. In- addition, the research was slightly in line with some studies. See Murkovita et al (2007);Sharma and Bajpai (2010); Adeloka (2012); Susanty and Miradipta(2013) whose views are that organizational commitment is the most important predator to job performance. If the goal of the individual is congruent to that of the organization, then there will be total commitment but if incongruent, the result is what we have in the Nigerian Local Government Systems. The interview proved that there is incongruence in organizational goal and that of the employees hence the lack of commitment. Some of the political office holders assumed duty with the intent to recoup what they had spent with a neat profit. Nigeria is a nation where you invest so much to win an election. Reference is made to the just concluded election of 2015. Moreover, most Nigerians contest for political positions to enrich themselves because that is the short-cut to richness This affects their will at work- positive disposition towards the application of these mechanism of public accountability is relatively lacking irrespective of the importance of the application of these mechanisms and the influence on performance. Local government staff claimed to be pleased with these mechanisms, in addition to have very good feelings about the application both during the interview session and filling of the questionnaires. But, we observed that due to selfish interest, paucity of salaries, desire to become wealthy, 
Nigerian mentality and other associated factors-local government functionaries were not disposed in the application of these mechanisms. These manifested in the working documents collected from some of these local governments. See appendix 1. We thereof suggest for change of attitude of local government functionaries and the elected for effective operations of institutional mechanisms of public accountability. Local government functionaries cannot post any real meaning in a setting where workers display negative attitude towards the application of these mechanisms.

The reason behind this ugly phenomenon lies in the fact that proper application of these mechanisms do not benefits them because everybody is interested in the share of the national cake. Workers often advance comments like "Olu Oyibo aburo olu Nnam" (government work is not my father's work). "Aku n'uba Nigeria agaghi agwu agwu" (Nigeria's resources are inexhaustible) etc With these aims at the back of their minds, the workers and the elected work to the benefit of their pockets. This is evidenced by the working documents collected in some of the local governments. There is therefore, urgent need for a serious change in the attitude of Nigerians before we can build a sustainable framework in the local government systems. Nigeria is among the richest country in the continent in terms of natural resources. Nigeria can boast of its oil, coal, tin, bauxite, and gold. Unfortunately, majority of the population especially, the people from NigerDelta-oil producing areas in the south, are yet to feel the impact of the revenues because of corruption, discrimination, and economic mismanagement. This, issue of corruption has also contributed to negative attitude towards the application of these mechanisms. There is urgent need to address the problems of corruption and this could be achieved through good governance. Good governance is indeed apparent because it is in short anticorruption.

Strengthening of capacities for decision making, resource management, and implementing development initiatives could only be achieved through good governance. Again, there is need for creation of an internal committee to monitor the implementation of these mechanisms installed in the system and the development of disciplinary measures and investigation procedures in institutional mechanisms with a view to keeping up with technology and increase efficiency of those responsible in this regard. Incorporate the principle of transparency into funding of local governments and ensure that money meant for the operations of local governments are judiciously managed. Moreover, legislative and other measures should be adapted to combat non-implementation of these mechanisms. Furthermore, government should adopt special measures to halve poverty, as this is one of the major issues confronting Nigeria local government workers. Local government workers should be adequately remunerated so as to encourage them to work hard and above all, to implement these mechanisms. there is need for civic education of local government workers to respect the public good, public interest, and awareness in the fight against non- implementation of these mechanisms of public accountability for the good of the grassroots. Government should also adopt national and legislative measures in order to punish those who failed to implement the mechanisms irrespective of whoever is involved. Adopt measures that citizens report instances of non-implementation without fear of consequent reprisals and promote socio-economic-development by removing obstacles to the implementation of these mechanisms of public accountability. Adopt other measures that may be necessary to prevent local governments from non-implementation of these mechanism; proscribe the activities of chairmen of local governments in the use of funds through illegal and corrupt practices. We also suggest for further areas of research.

\section{Conclusion}

This article examines the attitude of local government workers towards the application of Institutional mechanisms of public accountability with particular reference to Enugu state, which is in the eastern part of Nigeria. A good attitude wins friends at work and this in turn boost productivity and opportunities available to the organization. A very important predator which is organizational commitment is found to be lacking in the system and this negatively impacts on the performance of local governments in Nigeria-"The Giant of Africa". Another interesting finding is the negative attitude stereotype possessed by workers towards the application of these mechanisms which also impair the development of Nigeria local governments. Suggestions were therefore, made on how to correct this malaise.

\section{Appendix 1}

A total sum of N758,000.00 paid to sundry councilors of Igbo-Eze North Local Government Council for seminars and workshops attended within Enugu state such payments contravene the provision of establishment circular No. ENS/SSF/ED/RR/S.39/w/204 of $8^{\text {th }}$ February 2009, which forbids the payment of duty tour allowance for duty tours undertaken within the state. The detail of this is stated hereunder;

\begin{tabular}{|c|c|c|c|}
\hline S/" & Name of councilors & Total amount resealed & Remark \\
\hline \multicolumn{3}{|c|}{} \\
& 409
\end{tabular}




\begin{tabular}{|c|l|c|c|}
\hline 1. & Eke Fabian & $N 30,000.00$ & \\
\hline 2 & Chigbo Cosmas & $N 30,000.00$ & \\
\hline 3 & Nwabueze Vincent & $N 30,000.00$ & \\
\hline 4 & Eya Lawrence & $N 30,000.00$ & \\
\hline 5 & Atta Augustine & $N 30,000.00$ & \\
\hline 6 & Odo Patrick & $N 30,000.00$ & \\
\hline 7 & Eze Theophillus & $N 30,000.00$ & \\
\hline 8 & Odogu Michael & $N 30,000.00$ & \\
\hline 9 & Eze Jeremiah & $N 50,000.00$ & \\
\hline 10 & Odo Sylvannus & $N 50,000.00$ & \\
\hline 11 & Urama George & $N 50,000.00$ & \\
\hline 12 & Eze Emmanuel & $N 30,000.00$ & \\
\hline 13 & Oguche Joseph & $N 30,000.00$ & \\
\hline 14 & Tijani & $N 30,000.00$ & \\
\hline 15 & Eze Cosmos & $N 50,000.00$ & \\
\hline 16 & lyida Cletus & $N 50,000.00$ & \\
\hline 17 & Amedu Festus & $N 30,000.00$ & \\
\hline 18 & Idoko Silas & $N 50,000.00$ & \\
\hline 19 & Akor Silas & $N 30,000.00$ & \\
\hline 20 & Ojobor Benedict & $N 18,000.00$ & \\
\hline 21 & Awnwueze C.N. & 758.000 & (Ag. Treasurer) \\
\hline & & & \\
\hline
\end{tabular}

The payment of $\mathrm{N} 758,000$ to the councilors for conference attended within Enugu is not constitutionally right. The constitution specifically forbids such payment. This particular report is evidence that proved that local government staff posses negative stereotype towards the application of these mechanisms. Another example could be derived from the same working document from Igbo-Eze North. Irregular cash advance not accounted for. The sum of N140,000 was paid to the clerk of the council, Mr. G.I. Eze on payment voucher No. 30 of May 2010. This is for mobilizing 20 ward dance groups for the governors' visit to the local government area, alleged to have been scheduled for $9^{\text {th }}$ May 2010 . The only attachment to the payment voucher was a letter addressed to the executive chairman dated on $5^{\text {th }}$ May 2010. Mr. G.I. Eze where he stated that the total estimate cost required by the councilors for the visit stood at N260,000.00 as follows;

a. 20 buses for conveyance of the cultural dance groups at N5000.000. each 100.000

b. 20 buses to convey people from their wards at N000.000.100,000

2 buses to convey councilors to an fro 10,000

c. Entertainment for the dancing groups and people fro the wards 50,000

Out of this amount, the chairman approved only the sum of N140,000 for the exercise, which was collected by Eze G.I. on $8^{\text {th }}$ May 2000 , as evidenced by his signature in the payment voucher. There was no documentary evidence attached to the payment voucher to show that any of the councilors received any money from the clerk for that purpose. Some of the councilors interviewed admitted having received no amount from the clerk for the purpose. During the interview session by the audit inspection unit, Mr. Eze could not explain how he actually utilized the money but only claimed that he disbursed the money to the councilors without any documentary evidence. Furthermore, the case above depicts one of negative disposition to the application of these mechanisms. The law is very specific about the approval limit of the chairman. The chairman is required by law to gain the approval of FGPC before signing any amount above his approval limit. The Chairman who was supposed to lead by example is the one that contravenes the rules.

\section{Ezeagu Local Government: Irregular Award of Contract Paid for but not Executed}

The sum of N2000,000.00 was paid to Mr. Chukwudi egbo, Chudac Metal Structures of No. 166 Agbani Road, and Enugu on payment voucher No. 12 of December 2009 as part payment for the construction of two metal gates. The extract of the minutes of the meeting of Finance and General Purpose Committee of finance and general-purpose committee held on $10^{\text {th }}$ July 2009 disclosed that the committee considered three quotations for the construction of two gates and awarded the contract to Chudac Metal structure at the cost of 337,000. It was however discovered that there are no documentary evidence of any quotations for the job either by Chudac or any other company was attached to the payment voucher or produced on demand to audit office during verification. It was also observed that the structural drawings, other technical drawings and dimensions of the two gates together with the type of iron metals for the construction were not disclosed. 
Documentary evidence of any advertised invitation to tender for the construction of the two gates could not be produced during audit inspection. Only God knows how quotations in ordinary course of business could be computed and prepared by any company for the construction of two gates for which the technical drawings, specifications, dimensions, and types of iron materials for the construction were not disclosed. The arrangement for the execution of this contract is crude and contrary to the award of contact regulation reference chapter 17 of financial memoranda 2001. Regrettably, a jobbing order was neither issued for the job nor was contract agreement executed by both parties. There was therefore no contractual relationship between the local government council and Mr. Egbo. A letter of application for part payment of the sum of N200, 000.00 dated $2^{\text {nd }}$ September, 2009 was approved sheepishly by the chairman despite the fact that there was no contractual relationship between both parties and without even ascertaining the quantity or extent of work actually done by the competent authority- the Works Department. Physical inspection carried out by the audit officers revealed that the purported iron gates were not in existence. The arrangement for the execution of the purported project was irregular and the project was never executed yet the sum of $\mathrm{N} 200,000.00$ had already been paid.

Source: Ezeagu Audit Inspection Report 2010.

In this section you are required to answer high moderate or low

\begin{tabular}{|c|l|l|l|}
\hline \multicolumn{2}{|l|}{ Section B: Performance. Health Department } & & \\
\hline 1. & Payment of salaries as and due & & \\
\hline 2. & Supplies of materials to the health district center in your local government & & \\
\hline 3. & Provision for treatment of patience in your local government. & & \\
\hline 4. & Conducive environment/atmosphere for work. & & \\
\hline 5. & Influencing the lives of the community through the care and treatment of the unit & & \\
\hline Works Department & & \\
\hline 1. & Prompt payment of salaries and emoluments & & \\
\hline 2. & Maintenance of roads & & \\
\hline 3. & Capital projects approval and implementation & & \\
\hline 4. & Recurrent projects approval and implementation & & \\
\hline Education Department & & \\
\hline 1. & Prompt payment of salaries and emoluments & & \\
\hline 2. & Maintenance of primary schools in your local government & & \\
\hline 3. & Provision of facilities needed for quality education & & \\
\hline 4. & Provision of conducive environment for learning in your local government & & \\
\hline 5. & Regular checks of personnel in charge to ensure performance & & \\
\hline 6. & Implementation of the University Basic Education in your local government (UBE) & & \\
\hline 7. & Award of scholarship to intelligent candidates. & & \\
\hline
\end{tabular}

\section{References}

Agu, S.U. (2009). Institutional mechanisms for Public Accountability and performance in Nigeria local governments. Unpublished Doctoral Dissertation, University of Nigeria, Nsukka.

Ashworth, R. Boyne, G. and Delbridge, R. (2005). Institutional Pressures on Public Organizations: An Empirical Test of Isomorphism. Academy of Management Review 31, 4, 256, www.inst.prorg.

Audit Report (2004). Anaocha Local Government

Audit Report (2004). Igbo-Eze North Local Government

Audit Report (2004). Onitsha North local Government

Beyene, A. and Otobo, E. (1994). Public Administration in Africa: Past trends and emergency challenges. African Journal of Public Administration and Management

DiMaggio, P. and Powell, W. (1985). Interest and Agency in Institutional Theory. In Zucker (ed) Institutional Patterns and Organizations: Culture and Environmental Cambridge: Mass Balinger.

Donaldson, A. (1995). American Anti-Management Theories of Organization. Cambridge University Press; http/www.th.org.mgt theories.

Friendland, R. and Alford, R. (1991). Bringing society bank in symbols: Practices and Institutional Contradiction. In P.W. and D.P. (eds). The New Institutionalism Organizational Analysis. Chicago: University of Chicago Press.

Mobolaji, A. 2005). Local Governance in Nigeria: Problems and Prospect http/www.gov.nig

Okoli, F.c. (1998). An Introduction to the Theory and Practice of Local Government in Nigeria Perspective. Nsukka: Topmost Printing Press.

Okoye, U.O. (2006). Knowledge of aging among secondary school students in south eastern Nigeria. International Journal of 
Educational Gerontology. Vol 3 (6) pp 481-489.

Olu, G. (2002). Accountability and efficiency: Formal Controls and Performance Management in Nigeria local Government System ww.llaslisa.be/iias/ailigtri/ailitsun.htm.

Onor, S.O. (2002). Association of local Governments in Nigeria: Philosophy and Objectives In O.E. Iya and J Okoro (eds). Local Government Administration and Grassroot Democracy in Nigeria. Calabar: University of Calabar Press.

Pfeffer, J. and Salancik, G. (1978(. The External Control of Organization. New York Harper and Row

Eagle, A.H. and Chaiken,S.(1993). The Psychology of Attitudes, Fort Worth TX, Harcourt Brace Jovanovich.

Kalleberg. A.L. and Marden, P.V(1995) Organizational Commitment and Job Performance in the US Labor Force. Research in the Socilogy of Work, 5 1995, pp 235-57.

Khan, M.R. Ziauddin Jam. F.A. and Ramay M.I.(2010), The Impacts of Organizational Commitment on Employee. Job Performance. European Journal of Social Science. 15(3). 2010, pp 292-298

Markovits Y. Davis A. J. and Dick R.V(2007), Organizational Commitment Profiles and Job Satisfaction among Greek: Private and Public Sector Employees, International Journal of Cross Cultural Management, 7((1), pp 56-70.

Mathieu, J. E. and Zajac, D. M (1984), A Review and Meta-analysis of the Antecedents. Correlates, and Consequences of Organizational Commitment: Some Methodological Considerations. Journal of Applied Psychology, 69(3), pp. 372-378.

Meyer, J.P., Becker, T.E, and Vandenberghe C.(2004), Employee Commitment and Motivation: A Conceptual Analysis and Integrative Model, Journal of Applied Psychology, 89(3) pp 991-1007.

Meyer J.P and Allen N.(1984), Testing the "Side-bet Theory" of Organizational Commitment; Some Methodological Considerations. Journal of Applied Psychology 69(3),pp372-376

Meyer, J.P. Stanley, D.J. Herscovitch. L and Topolnytsky, L.(2002). Affective, Continuance, and Normative Commitment to the Organization: A Meta-analysis of Antecedents, Correlates, and Consequences, Journal of Vocational Behaviour, 61,(1) pp 20-52

Riketta, M. The Causal |Relation between Job Attitudes and Performance: A Meta-Analysis of Panel Studies. Journal of Applied Psychology. 93(2). 2009. Pp 472-481

Robbins, S.P. Organizational Behaviour: Concept, Controversies , Applications, Prentice-Hall, New Jersey, 2001.

Sharma, J.P. and Bajpai, N. Organizational Commitment and Its Impact on Job Satisfaction of Employees: a Comparative Study in Public and Private Sector in India. International Bulletin of Business administration, 9. 2010 pp 7-19.

Suliman, A and Lies, P, Is Continuance Commitment Beneficial to Organization? Commitment performance Relationship: A New Look. Journal of Managerial Psychology. 15(5), 2000, pp 407-422.

Susanty, A and Miadipta,R.(2013) Employye's Job Performance: The Effect of Attitude toward Works, Organizational Commitment and Job Satisfaction. Journal of Tekruk Industri (15) pp 13-24

Velnampy,T (2005), Job Attitude and Employees Performance of Public Sector Organizations in Jaffina District, Sri Lanka.

Wei, W.C. and Chu, S.H.(2008), Empirical Study on the Correlation among Personality Traits. Work Attitudes. Services Quality. Job Performances and Customers Satisfaction A Financial Holding Company in Taiwan, International Journal Lisrel, 1(2), pp 1-24 